\title{
South Korea's Geoeconomic Response to the United States' Geopolitical Approach
}

\author{
$\mathrm{Ki}-\mathrm{Su} \mathrm{Kim}^{1}$ \\ ${ }^{1}$ School of Foreign Languages, Peking University, Beijing, People's Republic of China \\ Correspondence: Kim Ki Su. E-mail: bdemba@hanmail.net
}

Received: January 22, 2020

Accepted: February 17, 2020

Online Published: March 30, 2020

doi:10.5539/ass.v16n4p25

URL: https://doi.org/10.5539/ass.v16n4p25

\begin{abstract}
The United States "Indo-Pacific strategy" itself entails geopolitics. Since 2017, the Indo-Pacific has emerged as a major strategic region for America's diplomacy and security. Against this backdrop, the Indo-Pacific strategy extends both the "Asia Rebalancing Strategy" and the "Asia-Pacific Security Alliance" regime to the Indian Ocean, while seeking to bring emerging countries, such as China and India, into the U.S.-led international order. Major East Asian countries are actively employing economic means to advance their geopolitical goal -reshaping the regional order in their own favor. The U.S. has shown a confrontational and exclusionary attitude toward China in terms of politics, economy and security, while the ASEAN has sought to promote inclusiveness by publicly expressing opposition to the exclusion of China. The ASEAN highlighted economic cooperation with China, while the U.S. focused on military and security aspects. The Indo-Pacific strategy will not be able to succeed without the participation of the ASEAN that serves as a crucial geopolitical link between the Indian and Pacific Oceans. Another important factor is that unlike former U.S. President Obama, who championed the Asia-Pacific rebalance, President Donald Trump does not show keen interest in the Indo-Pacific strategy. At the same time, President Moon Jae-in has been cautious about engaging in security issues that go beyond the Korean Peninsula or the Northeast Asia -- namely joining in any collective move to contain China. Currently, South Korea is grappling with the geopolitical challenges by expressing support for the ASEAN's geoeconomic approach. Instead of choosing whether to participate in the U.S. Indo-Pacific strategy, South Korea is seeking common ground between the strategy and its "New Southern Policy." In other words, the New Southern Policy is a kind of buffer zone. South Korea is taking a geoeconomic response that focuses on developing the regional economy rather than adhering to the strategic and military role of the U.S. Indo-Pacific strategy.
\end{abstract}

Keywords: geopolitics, geoeconomics, Asia strategic rebalance, Indo-Pacific strategy, ASEAN prospective on Indo-Pacific strategy, New Southern policy

\section{United States Indo-Pacific Strategy and Geopolitics}

Traditional geopolitics has assumed that such factors as accessibility, distribution of resources and race have a profound impact on relations between countries, and viewed countries fiercely competing to secure resources and markets as the essence of international relations. It was also understood that traditional geopolitics has disappeared with the end of the Cold War (Mead, 2014) (Note 1). However, a few events have signaled the return of geopolitics in international relations in East Asia. They are the rebalancing policy of the Obama administration, China's assertiveness in territorial disputes and Japan's aggressive responses to China's activities. For the U.S. and Japan, the rise of China is seen as an attempt to break down existing geopolitical agreements in East Asia, which have been established and maintained since the end of the Cold War. It is hard to deny such a return of geopolitics is having a significant impact on the dynamics of the international relations in East Asia.

The U.S. Indo-Pacific strategy itself involves geopolitical strategies. One of the changes seen as the implementation of the Indo-Pacific strategy was the renaming of the United States Pacific Command (USPACOM) into United States Indo-Pacific Command (USINDOPACOM) on May 31, 2018. This can be seen as a symbolic step that reflects increased connectivity between the Indian Ocean and the Pacific Ocean, and the growing importance of India to the United States. Since 2017, the Indo-Pacific has become a major strategic region for the U.S' diplomacy and security. On June 1, 2019, the United States Department of Defense (DoD) released a report that included measures to push forward the Indo-Pacific strategy, titled "Indo-Pacific Strategy Report: Preparedness, Partnership, and Promoting a Networked Region.” (Note 2) 
According to DoD's "Free and Open Indo-Pacific", the geographic scope of the Indo-Pacific starts from the U.S. west coast and reaches the west coast of India. Moreover, "free" means respect for sovereignty and independence of a nation with good governance and assurance of individual rights and liberties. "Open" covers freedom of navigation and overflight, peaceful resolution of disputes, fair and reciprocal trade based on open investment and transparent agreements. The report defines China, Russia, North Korea and transnational issues as threats in the region. Of these, it focuses on China. The report highlights the strategic competition has begun between the United States and China. It also argues that China is trying to overthrow the current regional order and is seeking regional hegemony. Of course, it is referring to persuasion to bring China into the rules-based regional order, but at the same time it also made clear that United States would not just sit back if Beijing tries to break the current order.

For the United States, the Indo-Pacific strategy is no stranger. Former President Obama has already taken his 'Pivot to Asia' scheme as part of the Indo-Pacific Strategy. Obama's strategy has re-regulated the Asian maritime domain to include the Indo-Pacific rim through various diplomatic efforts. The Obama administration has designated Sea Lines of Communication (SLOCs) in the Indo-Pacific basin as a major U.S. maritime interest in Asia and has stressed the importance of strengthening security cooperation with Australia, Singapore, Indonesia and India.

President Trump's Indo-Pacific strategy has implications for overcoming the limitations of existing regional concepts in the Asia-Pacific and their basic strategies. The Indo-Pacific Strategy extends both the Asian Rebalancing Strategy and the Asia-Pacific Security Cooperation regime to the Indian Ocean. It links the Pacific region with the Indian Ocean to build alliances and partnerships. In this way, through cooperation and containment, the U.S. aims to bring emerging economies, such as China and India, into the U.S.-led international order.

\section{ASEAN Outlook on Indo-Pacific Strategy}

The "ASEAN Outlook on the Indo-Pacific" (Note 3), announced by ASEAN countries in June 2019, is a document that contains the 10 ASEAN countries' united outlook on the U.S. Indo-Pacific strategy and envisages the "ASEAN Centrality" as the underlying principle.

First, "ASEAN Centrality" stresses the importance of ASEAN members playing the central role with the momentum in establishing regional cooperation in East Asia. The ASEAN chair will take shape in the form of hosting the relevant summit while concurrently chairing the regional consultative body. The ASEAN centrality from "ASEAN Outlook" reflects the efforts of ten ASEAN members to secure the geopolitical independence and sovereignty between the U.S. and China. On August 2019, Lee Sun-jin, a former South Korean ambassador to Indonesia, has explained that "the U.S. has shown a confrontational and exclusionary attitude toward China in terms of politics, economy and security, while ASEAN pursued inclusiveness by declaring opposition to the exclusion of China." Mr. Lee also said "the ASEAN highlighted economic cooperation with China, while the US is focusing on military and security aspects."

Following ASEAN's response, the Indo-Pacific strategy has also shifted its focus to economy. The US secretary of state has emphasized economic cooperation rather than politics and security during the ASEAN Regional Forum in August, 2018. Following the Thailand conference in 2019, the United States hosted the Indo-Pacific Business Forum, and U.S. Secretary of Commerce Wilbur Ross emphasized economic and regional cooperation in his keynote speech. The Indo-Pacific strategy will not be able to succeed without the participation of ASEAN members which serves as a crucial geopolitical point linking the Indian and Pacific Oceans. Another important factor is that unlike former U.S. President Obama, who has fully supported the Asia-Pacific rebalancing, President Trump does not show keen interest in the Indo-Pacific strategy. Consequently, the U.S. has sent a downgraded delegation to the East Asia Summit (EAS) in 2019. Robert C. O'Brien, National Security Advisor, attended the 2019 EAS on behalf of President Trump and this was the third consecutive year that President Trump has skipped the EAS. The EAS is a forum held annually by leaders of 18 countries including ASEAN members, the U.S., Russia, Australia, India, South Korea, Japan and China. In response, only three leaders from the ASEAN attended the U.S.-ASEAN summit. They were Thailand, the current chair, Vietnam, the next chair, and Laos, the coordinator between the bloc and the U.S., while other ASEAN members sent foreign ministers. Later on, the U.S. had, again, invited ASEAN leaders in early 2020 to hold a summit in the U.S., but there was no immediate response . Meanwhile, local media strongly criticized United States' "disrespect for Asia."

After the end of the Cold War in the 1990s, the U.S. has promoted its value to the Asia-Pacific region through international organizations based in Asia and established itself as a regional leader. Despite the ideological differences in the region, the U.S. has established market economy and free trade through the Asia-Pacific 
Economic Cooperation (APEC). The Obama administration led and rallied supporters of the Trans-Pacific Partnership (TPP), declaring that China cannot take center stage in the regional economic order. In contrast, President Trump is damaging the platform for regional cooperation with his withdrawal from the TPP and his absence from the EAS.

Meetings in 2019 were considered the last chance to imprint the U.S. leadership within the region ahead of the U.S. presidential election in 2020, however, they were skipped. With the U.S. withdrawing from the TPP and skipping the EAS, it will face deeper isolation if the Regional Comprehensive Economic Partnership (RCEP) is established without the U.S., while China is fast filling the void left by the U.S.

\section{South Korea's Response to Indo Pacific Strategy}

The "2019 ROK-ASEAN Commemorative Summit" was held on Nov. 26, 2019. Thai Prime Minister Prayut announced the joint statement (Note 4) and said "we expressed our gratitude for the Republic of Korea's continued support for ASEAN centrality in the evolving regional structure, including support for the ASEAN Outlook on the Indo-Pacific Strategy.” This suggested that South Korean President Moon attempted to circumvent U.S. pressure on Seoul to join its regional initiative by supporting the ASEAN Outlook on the Indo-Pacific Strategy. This is evidenced by the results of past consultations between Seoul and Washington over this issue. The joint statement between the U.S. and South Korea on June 30, 2017, says, "President Trump and President Moon affirmed that the United States and the South Korea will work together to support and uphold the rules-based order in the Asia-Pacific region." Also in November 2017, President Trump suggested that President Moon, who was on the Asian tour, to join the effort to ensure security in the Indo-Pacific region. In the joint statement on Nov. 8, President Trump stressed that the ROK-U.S. alliance built on common values such as mutual trust and shared values of freedom, democracy, human rights, and the rule of law, are key pillars of security, stability and prosperity in the Indo-Pacific region.

Later, Kim Hyun-chul, a presidential economic advisor who was accompanying President Moon in Jakarta, told reporters that the ASEAN lies in a strategically crucial position, and at the same time noted that although Japan is trying to construct the Indo-Pacific line that links India, Australia, Japan and the United States, South Korea does not necessarily have to join it. His remarks appeared to be a denial of what was emphasized during the Moon-Trump summit. Amid this confusion, another senior presidential aide told reporters that President Trump had made a proposal to President Moon that South Korea join the Indo-Pacific initiative. But he said that for Moon, the concept was new -- a reason why it was not mentioned in the post-summit statement to the press. He added that President Trump had stressed that initiative, but that does not mean President Moon has agreed to join it. The presidential office Cheong Wa Dae also said that there need to be further internal consultations to determine whether the initiative befits the allies' shared strategic goals though part of it is in line with South Korea's policy stance to diversify its diplomacy. This reaffirmed Seoul's position to distance itself from the initiative for the time being but showed its desire to avoid the optics of flatly rejecting the concept.

On August 24, 2018, a "New Southern Policy and Indo-Pacific Strategic Consultation" was held in Seoul, where all director general-level officials from the Korean Foreign Ministry and the U.S. Department of State participated. South Korea and U.S. stated that "the two sides especially took note of the complementary nature of the New Southern Policy and the Indo-Pacific Strategy, both of which pursue openness, inclusiveness, and transparency. They also agreed to continue efforts to find common ground between the two countries' policies so that the two countries' efforts can give impetus to each other to create synergy, and thereby expand cooperation between the South Korea and the U.S. in a wider range of areas." At another ROK-U.S. summit meeting held in Seoul on June 30, 2019, President Moon stated, "The Asia Pacific region is a core region for maintaining peace and prosperity for both countries." He added, "Under the regional cooperation principles of openness, inclusiveness and transparency, we have agreed to put forth harmonious cooperation between Korea's New Southern Policy and the United States' Indo-Pacific Strategy."

South Korea has been vague on the issue of backing the Indo-Pacific strategy. This stance is also shown in the U.S. Department of Defense report (Note 5). Among the allies, Australia and Japan clearly have a clear role within the Indo-Pacific strategy. Japan is referred to as "the cornerstone of peace and prosperity in the Indo-Pacific" and Australia as "collaborating to ensure the security of the Indo-Pacific region into the future." Furthermore, the term "Indo-Pacific" is used in references to other major countries as well. On the other hand, South Korea is referred to as the "linchpin of peace and prosperity in Northeast Asia, as well as the Korean Peninsula" without any mention of the Indo-Pacific. Most of strategic cooperation efforts with South Korea is virtually limited to issues of North Korea and the Korean Peninsula. The term Indo-Pacific was not used at all in about two pages dealing with South Korea. President Moon is maintaining a cautious approach to security 
cooperation for issues outside the Korean Peninsula, in other words, containing China.

\section{Geoeconomic Response to Indo-Pacific Strategy}

Geoeconomics has been taking on greater importance when it comes to a shift in the East Asia regional order. Robert Blackwill and Jennifer Harris (2016) defined "geoeconomics" as the "use of economic instruments to promote and defend national interests, and to produce beneficial geopolitical results" and "the other nations' economic actions on a country's geopolitical goals." From this point of view, major East Asian countries are actively utilizing economic means to achieve the goals of shaping a regional order in their own favor. Geopolitics and geoecomics, although they may be deployed separately within their own dynamic, tend to develop in close connection with each other. These complex interactions are also the factor that forces major East Asian countries to pursue seemingly contradictory movements of conflict and cooperation. Furthermore, the importance of economic means will be highlighted even more in the process of the United States and China re-designing the world order and the East Asian regional order. The coordination of economic relations with East Asian countries is likely to act as a fundamental factor affecting competition and cooperation between the United States and China in the future (Swain \& Eberstadt et al., 2015).

Negotiations for the Regional Comprehensive Economic Partnership (RCEP) made progress at the EAS in Thailand in November 2019. The RCEP negotiation is aimed at creating a multilateral FTA, or a shared trade and investment norm, involving ASEAN members plus 16 countries representing Asian economies such as South Korea, China, Japan, India, Australia and New Zealand. There were various bilateral FTAs among these nations, but no multilateral agreements encompassing the whole. As China and Japan have confrontational perspectives, the ASEAN presented a compromise in 2012 and led the negotiations. But Indian Prime Minister Modi refused to agree to the RCEP out of concern it would increase trade deficit in India due to the weak manufacturing market. At the same time, the 16 countries of the RCEP are struggling from the U.S.-China trade dispute. The trade dispute is expected to last for a considerable period of time, therefore, these countries are preparing for self-rescue measures. The RCEP negotiations are part of the effort to ease the heavy reliance on U.S.-China trade, while developing and expanding regional value chains.

These countries had a similar experience in the past. The ASEAN+3 summit agreement during the 1998 Asian financial crisis turned the crisis atmosphere in the region into a hopeful mood and quickly restored the East Asian economy, making it one of the world's top three economies along with the United States and the EU today. There was optimism that the RCEP deal, if concluded, would have provided new vitality to the international economy, although India rejected it at the last minute. Despite the refusal, the 15 countries agreed to adopt the RCEP free-trade deal and they are taking steps to approve it domestically. South Korea, China and Japan have also joined the deal. For India, the door is still open, but it is looking for an alternative way not to be distracted by U.S.-China competition. It is important to note the change in the U.S. attitude which was made when the ASEAN officially declared an inclusive policy for China or its opposition to China's containment, and focused on the economy rather than military and security aspects through its "ASEAN Outlook on the Indo-Pacific."

Instead of choosing whether to participate in the Indo-Pacific strategy, South Korea has set up a buffer zone called "New Southern Policy." (Note 6) South Korea is trying to resolve the geopolitical challenges through a geoeconomic approach and by expressing support for ASEAN's decision. It is expected to seek a geoeconomic solution that focuses on developing regional economic links rather than sticking to the strategic and military role of the Indo-Pacific strategy.

\section{References}

ASEAN. (2019). ASEAN Outlook on Indo-Pacific.

ASEAN. (2019). ASEAN-Republic of Korea Joint Vision Statement for Peace, Prosperity and Partnership.

ASEAN. (2019). Joint Statement of the ASEAN-ROK Commemorative Summit.

Brzezinski, Z. (1997). The Grand Chessboard. New York : Basic Books. https://doi.org/10.2307/1149289

Doss, K. (2007). Geopolitics: A Very Short Introduction. New York: Oxford University Press. https://doi.org/10.1093/actrade/9780198830764.001.0001

Flint, C. (2006). Introduction to Geopolitics. London: Routledge. https://doi.org/10.4324/9780203503768

Fukuyama, F. (1992). The End of History and the Last man. New York: The Free Press. https://doi.org/10.1086/ahr/97.3.817

Kang, S. (2018). U.S. Indo-Pacific Initiative as of Geoeconomics. Institute of Foreign Affairs \& National Security. 
Lee, K. (2018). Belt and Road Initiative and New Northern Policy New Southern Policy. Seoul: Bookstar.

Lim, D.-S. (1999). Geopolitics: Theory and Practice. Seoul: Bobmunsa.

Luttwak, E. (1990). From Geopolitics to Geo-Economics: Logic of Conflict, Grammar of Commerce. The National Interest, (20), 17-23. Retrieved from www.jstor.org/stable/42894676

Mackinder, H. (1996). Democratic Ideals and Reality. Washington, DC: National Defense University Press.

Mead, W. (2014). The Return of Geopolitics: The Revenge of the Revisionist Powers. Foreign Affairs, 93(3), 69-79. Retrieved from www.jstor.org/stable/24483407

Nye, J. S. Jr. (2002). The Paradox of American Power. New York: Oxford University Press. https://doi.org/10.2307/798269

Park, J.-K. (2013). China-US. Relations in East Asia: Strategic Rivalry and Korea's Choice. CSIS Korea Chair.

Ross, R. (2013). US Grand Strategy, the Rise of China, and US National Security Strategy for East Asia. Strategic Studies Quarterly, 7(2), 20-40. Retrieved from www.jstor.org/stable/26270764

Spykman, N. J. (1944). The Geography of the Peace. New York: Harcourt, Braceand Company. https://doi.org/10.2307/2192825

U.S. Department of Defense. (2019). Indo-Pacific Strategy Report: Preparedness, Partnerships, and Promoting a Networked Region.

U.S. State of Department. (2019). A Free and Open Indo-Pacific: Advancing a Shared Vision.

\section{Notes}

Note 1. The Mead (2014), who advocated the return of geopolitics, argues that the peace that was built during the Cold War was in fact a result of forgetting that it was built on a geopolitical basis that was formed around the United States and Western countries.

Note 2. The U.S. State Department released its second report, titled "A Free and Open Indo-Pacific: Advancing a Shared Vision" on November 4, 2019. The report cited the cyber threat as the most urgent transnational threat, stressing that the U.S. is increasing its support to strengthen cyber security to prevent malicious activities from North Korea, China, Russia and other countries.

Note 3. ASEAN issued a chairman's statement at the 34th summit in Bangkok, Thailand, on June 23, 2019, stating that it adopted an ASEAN Outlook on India and the Pacific Ocean. The statement cited five main principles from the ASEAN Outlook: ASEAN centrality and engagement, complementarity, regional order based on transnational law, and facilitate economic exchanges in the region.

Note 4. "2019 ROK-ASEAN Commemorative Summit" under article 6 has announced the "ROK-ASEAN Joint Statement for peace, prosperity, and partnership" and the "Joint Statement of the ROK-ASEAN Commemorative Summit"

Note 5. State Department released a report on June 1, 2019, titled "Indo-Pacific Strategy Report: Preparedness, Partnerships, and Promoting a Networked Region".

Note 6. "New Southern Policy" is officially announced by President Moon at the "2017 ROK-Indonesia Business Forum" on November 9, 2017. The "New Southern Policy" is built on so-called "3P", which are "People, Peace, and Prosperity." The purpose of the policy is to increase the level of cooperation with ASEAN countries to the level of the United States, China, Japan and Russia.

\section{Copyrights}

Copyright for this article is retained by the author(s), with first publication rights granted to the journal.

This is an open-access article distributed under the terms and conditions of the Creative Commons Attribution license (http://creativecommons.org/licenses/by/4.0/). 